\title{
Altered glycosylation of integrin adhesion molecules in colorectal cancer cells and decreased adhesion to the extracellular matrix
}

Free University of Berlin, Klinkum Steglitz, Medical Department

B v Lampe

A Stallmach

E O Riecken

Correspondence to: Andreas Stallmach, Freie Andreas Stallmach, Freie Universität Berlin, Klinikum Steglitz, Medizinisch Klinik und Poliklinik, Abteilung für Innere Medizin mit Schwerpunkt Gastroenterologie, Hindendurgdamm 30, 1000 Berlin 45, Germany.

Accepted for publication 22 September 1992

\author{
B v Lampe, A Stallmach, E O Riecken
}

\begin{abstract}
The integrin mediated interactions between tumour cells and the surrounding extracellular matrix are thought to play crucial parts in the complex process of invasion and metastasis. It has been previously shown that the expression of integrins is differently diminished in a chainspecific manner in human colorectal cancer. To further characterise the integrins still expressed in colorectal carcinomas, immunoblots with monoclonal antibodies against the $\beta_{1}$ integrin subunit have been performed. In isolated cell membranes of colorectal cancers a second smaller $\beta_{1}$ chain (105 kD nonreduced) was found as well as the mature $\beta_{1}$ chain (116 kD non-reduced) present in normal mucosa of the colon. This smaller $\beta_{1}$ chain comigrates with the diminished glycosylated precursor form of the $\beta_{1}$ chain. The role of $N$ glycosylation for the function and expression of integrins in vitro was therefore investigated, with deoxymannojirimycin (DMJ) and deoxynojirimycin (DNJ) as specific inhibitors of N-glycan processing. Pretreatment of human colon adenocarcinoma derived HT-29 cells with DMJ resulted in an expression of the $105 \mathrm{kD} \beta_{1}$ precursor chain and of smaller forms of the $\alpha_{1}, \alpha_{3}, \alpha_{6}$, and $\alpha_{v}$ integrin subunits in a time and dose dependent manner. HT-29 cells treated with DMJ adhered poorly to laminin ( $8 \%$ of untreated controls), collagen type IV $(40 \%)$, and fibronectin (35\%). Pretreatment of the cells with DNJ did not alter the molecular weight of the integrin chains expressed and reduced HT-29 adhesion to laminin and fibronectin only to $68 \%$ and $49 \%$ respectively. Adhesion to collagen type IV was increased to $124 \%$ by DNJ. These results show that $\mathrm{N}$ glycan processing is essential for the function and expression of integrins in human colorectal cancer cells. An altered glycosylation of these adhesion receptors may contribute to a more invasive or metastatic phenotype in colorectal cancer.

(Gut 1993; 34: 829-836)
\end{abstract}

Invasion and metastasis largely determine the clinical course of colorectal carcinomas. Despite multiple clinical trials survival from colorectal carcinomas after optimal surgical removal of the primary tumour has not significantly improved in the past 40 years. ${ }^{1}$ There is general agreement that a better understanding of the mechanisms of invasion and metastasis will lead to the development of new and more successful treatment strategies. During infiltrative growth and metastasis the transformed epithelial cells have to penetrate the basement membrane of the organ and metastasising tumour cells have to traverse vascular basement membranes on the way to tissue invasion from the circulation. The initial step of this migration through basement membranes is thought to be the adhesion of tumour cells, which is mainly mediated through binding of extracellular matrix components to tumour cell surface receptors. ${ }^{2}$ In this context the family of integrins is of interest. Integrins are noncovalently associated dimers of one $\alpha$ and one $\beta$ subunit. As originally described, ${ }^{3}$ integrins were divided into three sub-families, each with a common $\beta$ subunit capable of associating with a specific group of $\alpha$ subunits. More recent work has shown that there are at least 13 different $\alpha$ subunits and eight $\beta$ subunits, and that certain $\alpha$ subunits can combine with more than one $\beta$ subunit (for reviews see ${ }^{46}$ ). The classical receptors for extracellular matrix components are found in the $\beta_{1}$ subfamily (synonymous with the very late activation antigens (VLAS)). ${ }^{7}$ The $\beta_{1}$ subfamily comprises at least eight related complexes, each consisting of a $\beta_{1}$ chain with a distinct $\alpha$ chain companion. Members of the $\beta_{1}$ subfamily include receptors for fibronectin (VLA-3, VLA-4, VLA-5, and the $\alpha_{v} \beta_{1}$ complex), ${ }^{8}$ laminin (VLA-1, VLA-2, VLA-3, VLA-6, and VLA-7) and collagen types I and IV (VLA-1, VLA-2, and VLA-3). Most of these receptors are promiscuous in their ligand recognition, but VLA-5 and VLA- 6 seem to be specific for fibronectin and laminin respectively. ${ }^{49}$

It was previously shown that during the process of malignant transformation in the large intestine the expression of integrins was changed in a typical pattern. ${ }^{10-12}$ Compared with normal colonic epithelial cells, the expression of the $\alpha_{3}$ and $\alpha_{5}$ chains was already greatly reduced in adenomas, and completely lost in most colon carcinomas. By contrast, the $\alpha_{6}, \beta_{1}$ and $\beta_{4}$ expression was maintained in adenomas, whereas the transformation from benign to malignant neoplasms associated with infiltrative growth was characterised by diminished expression of $\alpha_{6}$ and $\beta_{4}$ chains.

An altered expression of such adhesion molecules may influence the aggressiveness of local infiltrative growth and metastasis in human cancers. As well as a changed pattern of integrins in carcinomas, differences in their functional state may cause pathological cell matrix interactions. In this context it is noteworthy that if maturation of glycans on VLA- 5 was blocked, the receptor subunits remained non-functional despite apparently correct assembly and insertion into the plasma membrane. ${ }^{13}$ Because 
the pattern of glycosylation of cell surface components is altered in colorectal cancer, ${ }^{14}$ we have analysed expression of integrins in cell membranes of colorectal carcinomas and the adjacent normal colonic mucosa with regard to the state of glycosylation. Also, the role of $\mathrm{N}$-linked oligosaccharide processing on the cell surface expression and the function of $\beta_{1}$ integrins in human colon adenocarcinoma derived HT-29 cells were studied.

\section{Materials and methods}

REAGENTS

Fibronectin, isolated from human plasma was obtained from Boehringer Mannheim (Mannheim, Germany). Murine EngelbrethHolm-Swarm tumour derived laminin and type IV collagen were purchased from Collaborative Research Inc (Bedford, MA, USA) Cell culture reagents were purchased from Gibco BRL (Berlin, Germany). The glycosylation inhibitors desoxymannojirimycin and other reagents, if not otherwise mentioned, were obtained from Sigma (Deisenhofen, Germany). Carrier free $\mathrm{Na}^{125}$ I was from Amersham (Buckinghamshire, UK). Protein-A-sepharose was purchased from Pharmacia (Uppsala, Sweden).

\section{ANTIBODIES}

The monoclonal antibodies against integrin chains used were anti- $\alpha_{1} \mathrm{mAB}$ TS2/7 ${ }^{15}$ (T-CellScience), anti- $\alpha_{2} \mathrm{mAB} \mathrm{Gi}^{16}$ (Immunotech, Luminy, France), anti- $\alpha_{3} \mathrm{mAB}$ VM2 ${ }^{17}$ (gift of VB Morhenn, Menlo Park, CA), anti- $\alpha_{4} \mathrm{mAB}$ P4G9, ${ }^{18}$ anti- $\alpha_{5} \mathrm{mAB}$ P1D6, ${ }^{19}$ and anti- $\alpha_{\mathrm{v}} \mathrm{mAB}$ $\mathrm{AMF}^{20}$ (Telios Inc, San Diego, CA), anti- $\alpha_{6}$ $\mathrm{mAB} \mathrm{GOH}^{21}$ (donated by A Sonnenberg, Amsterdam, The Netherlands), anti- $\beta_{1} \mathrm{mAB}$ 4B422 (Coulter Clone, Krefeld, Germany), anti$\beta_{2}$ mAB MHM2323 (Dako, Hamburg,

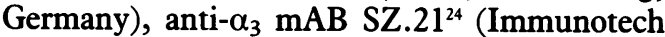
SA, Luminy, France), and anti- $\beta_{4} \mathrm{mAB} 3 \mathrm{El}^{25}$ (Telios Inc, San Diego, CA).

FITC-conjugated goat antimouse TgG or goat antirat TgG antibodies were purchased from Dako (Hamburg, Germany). Alkaline-phosphatase-conjugated antimouse or antirat IgG antibodies were from Sigma (Deisenhofen, Germany)

\section{TISSUES}

Intestinal tissues were obtained from eight patients (five men and three women, age range 52 to 82 years) with colorectal adenocarcinomas. In all cases, macroscopically and histologically normal adjacent mucosa $(10 \mathrm{~cm}$ from the primary tumour) as well as tumour tissues were examined. Surgical resection specimens were obtained from the Department of Surgery at the Steglitz Medical Center immediately after their removal. After extensive washing in phosphate buffered saline (PBS; pH 7.2), normal mucosa scrapings and tumour tissues were frozen in liquid nitrogen and stored at $-80^{\circ} \mathrm{C}$ until use.

\section{ISOLATION OF CELL MEMBRANES}

Cell membranes of human colorectal carcinomas and normal mucosa were prepared as described by Maeda et $a l^{26}$ with minor modifications. Briefly, tumours or mucosal scrapings were homogenised in TEA buffer $(250 \mathrm{mM}$ sucrose, $10 \mathrm{mM}$ triethanolamine ( $\mathrm{pH} \mathrm{7.6)}$ containing $1 \mathrm{mM}$ phenylmethylsulphonylfluoride (PMSF) and $1 \mathrm{mM}$ N-ethylmaleimide as protease inhibitors) on ice and centrifuged at $1000 \mathrm{~g}$ for 10 minutes. The supernatant liquid was centrifuged for 20 minutes at $19500 \mathrm{~g}$. The fluffy white upper layer of the double pellet was resuspended in $15 \mathrm{ml}$ of TEA buffer and loaded on $10 \mathrm{ml} \mathrm{41 \%}$ sucrose. After centrifugation for 60 minutes at $96000 \mathrm{~g}$, cell membranes were collected as a white interfacial band and pelleted by centrifugation at $48000 \mathrm{~g}$ for 30 minutes. The pellet was analysed for ouabain sensitive $\mathrm{Na} / \mathrm{K}$ ATPase as a marker for basolateral cell membranes according to Evans. ${ }^{27}$

\section{CHARACTERISATION OF INTEGRINS BY} IMMUNOBLOTTING

Equal amounts of cell membrane protein from normal and carcinoma tissue were boiled for five minutes in SDS sample buffer and analysed by SDS polyacrylamide gel electrophoresis according to $\mathrm{Laemmli}^{28}$ with $7 \%$ resolving gels. To identify $\beta_{1}$ integrins, resolved cell membrane proteins were transferred to nitrocellulose as described by Towbin et al. ${ }^{29}$ Nitrocellulose strips were blocked with blocking buffer (PBS containing $0 \cdot 1 \%$ sodium azide, $0 \cdot 3 \%$ TWEEN, and $2 \%$ powdered non-fat milk) at $4^{\circ} \mathrm{C}$ overnight and incubated with monoclonal antibodies against the integrin $\beta_{1}$ chain diluted 1:100 in blocking buffer for 60 minutes at room temperature. At the end of the incubation period, strips were washed three times for 30 minutes with blocking buffer. Bound antibodies were detected with antimouse-IgG antibodies coupled to alkaline phosphatase by the APAAP technique.

\section{CELL CULTURES}

The human colonic adenocarcinoma cell line HT-29 was obtained from the American Type Culture Collection (ATCC, USA). HT-29 cells were routinely cultured in Dulbecco's modified Eagle's medium ( $4.5 \mathrm{~g} / 1$ glucose) supplemented with $10 \%$ heat inactivated fetal calf serum in $8 \%$ $\mathrm{CO}_{2}$ in air at $36.5^{\circ} \mathrm{C}$. Media routinely changed three times a week.

Inhibitors of glucosidase I (deocynojirimycin (DNJ)) and mannosidase I (1-deoxymannojirimycin (DMJ)) were used at optimum concentrations, as specified for HT-29 cells. ${ }^{30}$ Stock solutions of inhibitors were made and serially diluted in the culture media. Cells were preincubated in the presence of inhibitors of different concentrations for four to 48 hours before radiolabelling, cytofluorometry, or cell adhesion experiments, depending on the nature of the experiment as described in the text and figure legends. No significant loss of cell viability resulted from pretreatment as judged by trypan blue exclusion tests. 
CELL-SURFACE LABELLING

Cell surface proteins were iodinated by the lactoperoxidase method as described by Hynes and Wyke. ${ }^{31}$ Briefly, confluent cell layers in $25 \mathrm{~cm}^{2}$ culture bottles were washed twice with $\mathrm{Ca}^{++} / \mathrm{Mg}^{++}$free PBS. Cells were harvested by incubation with $1 \mathrm{mM}$ EDTA in tris buffered saline for 20 minutes and centrifuged at 1000 rpm for 10 minutes. A pellet of $10^{7}$ cells was resuspended in $360 \mu \mathrm{l}$ HEPES-buffered saline (HBS) containing $150 \mu \mathrm{g}$ lactoperoxidase and $1 \mathrm{mCi}$ of carrier free $\mathrm{Na}^{125} \mathrm{I}$. The iodination reaction was initiated by adding $19 \mu \mathrm{l} 0.1 \%$ $\mathrm{H}_{2} \mathrm{O}_{2}$. After incubation on ice for five minutes with intermittent swirling, another $19 \mu \mathrm{l}$ aliquot of $0 \cdot 1 \% \mathrm{H}_{2} \mathrm{O}_{2}$ was added, and the reaction was continued for another 10 minutes. Unbound ${ }^{125} \mathrm{I}$ was removed by washing the cells three times with HBS. Labelled cells were extracted in $500 \mu \mathrm{l}$ of $200 \quad \mathrm{mM} \quad$ O-octyl- $\beta$ D-glucopyranoside in HBS containing $1 \mathrm{mM}$ PMSF with swirling of 20 minutes at $4^{\circ} \mathrm{C}$. Extracts were clarified by centrifugation.

\section{IMMUNOPRECIPITATION}

Immunoprecipitation with $\mathrm{mABs}$ was carried out as described by Sonnenberg et $a l^{32}$ with the modification: cell extracts were first incubated overnight at $4^{\circ} \mathrm{C}$ with $10 \mu \mathrm{l}$ of the specific antibody and $10 \mu \mathrm{l}$ of a species specific polyclonal rabbit IgG (Dako, Hamburg, Germany) antibody and then for an incubation period of one hour with $9 \mathrm{mg}$ protein $\mathrm{A}$ sepharose at $4^{\circ} \mathrm{C}$. After centrifugation at $5000 \mathrm{rpm}$ for 10 minutes, the pelleted sepharose was washed twice with

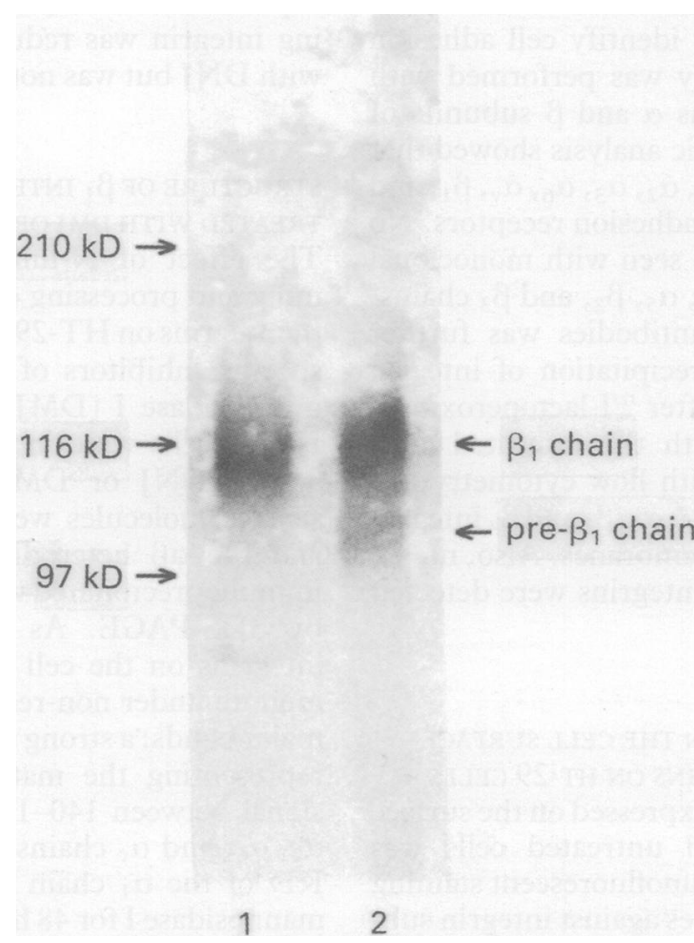

Figure 1: Immunoblot of the integrin $\beta_{1}$ chain in isolated cell membranes from human colonic carcinoma and normal colonic mucosa. Equivalent amounts of cell surface protein from human colonic carcinoma (2) and normal mucosa of the same patient (1) were resolved by SDS-PAGE under non-reducing conditions with $7 \%$ polyarcylamide gels, blotted onto nitrocellulose and incubated with monoclonal antibody against the integrin $\beta_{1}$ chain. Staining was performed with an alkaline phosphatase coupled second antibody.
$10 \mathrm{mM}$ Tris/HCI (pH 8.0), $0.5 \%$ sodiumdeoxycholate, $1 \%$ nonidet $\mathrm{P} 40$, and $0 \cdot 1 \%$ SDS. The absorbed protein was eluted by boiling the pellet for five minutes in double concentrated SDS sample buffer with or without dithiotreitol as reducing agent. After polyacrylamide gel electrophoresis (see earlier) with $7 \%$ resolving gels, radioactive peptides were visualised after drying the gel at $60^{\circ} \mathrm{C}$ by exposure to Kodak $\mathrm{X}$-Omat film at $-80^{\circ} \mathrm{C}$ for three to five days depending on the experiment.

\section{QUANTIFICATION OF INTEGRINS BY FLOW CYTOMETRY}

Flow cytometric analysis of expression of integrins on inhibitor treated and untreated HT-29 cells was conducted essentially as described..$^{33}$ Briefly, after trypsination, HT-29 cells $\left(2 \times 10^{5}\right)$ were incubated with monoclonal antibodies against different integrin subunits (see earlier) diluted 1:5 to 1:50 with FACS buffer (PBS containing $10 \%$ FCS and $0 \cdot 1 \%$ sodiumazide) in a total volume of $50 \mu \mathrm{l}$ for one hour at $4^{\circ} \mathrm{C}$. After two washes with $1 \mathrm{ml}$ FACS buffer, cells were incubated with FITC conjugated goat antimouse IgG or goat antirat IgG antibodies diluted 1:10 for one hour at $4^{\circ} \mathrm{C}$, followed by another two washes. Non-specific staining was assessed by omission of the primary antibody. Cells were then analysed on a FACSCAN (Becton Dickinson) flow cytometer.

\section{ADHESION ASSAYS}

Cell adhesion assays were described recently in detail. ${ }^{34}$ Briefly, microwells were coated with intact mouse laminin, type IV collagen, human serum fibronectin, or bovine serum albumin (BSA) for 90 minutes at $36^{\circ} \mathrm{C}$ and washed once with PBS. HT-29 cells were washed with PBS and harvested by a 10 minute incubation with $0.05 \%$ trypsin/0.02\% EDTA 24 hours after reaching confluency. The reaction was stopped by addition of $10 \%$ fetal calf serum in DMEM, cells were pelleted by centrifugation (300 $\mathrm{g} / 10 \mathrm{~min}$ ) and resuspended in serum free medium. Cells (50000) in serum free medium were added to each coated well and incubated for various times at $36^{\circ} \mathrm{C}$. At the end of the incubation period, plates were gently washed twice with $100 \mu$ l of PBS to remove unattached cells. After staining, dishes were photographed (Yashica, Ilford HP5 films), and adherent cells were counted from the photographs. To test the

Integrin expression in HT-29 cells

\begin{tabular}{lcc}
\hline Monoclonal antibody & Positive cells & Intensity \\
\hline$\alpha_{1}$ & $60 \cdot 3(31 \cdot 0)$ & $10 \cdot 7(1 \cdot 5)$ \\
$\alpha_{2}$ & $98 \cdot 5(1 \cdot 1)$ & $44 \cdot 1(5 \cdot 4)$ \\
$\alpha_{3}$ & $97 \cdot 7(1 \cdot 9)$ & $38 \cdot 3(15 \cdot 1)$ \\
$\alpha_{4}$ & $2 \cdot 8(0 \cdot 1)$ & $3 \cdot 3(2 \cdot 1)$ \\
$\alpha_{5}$ & $4 \cdot 8(1 \cdot 4)$ & $3 \cdot 7(1 \cdot 1)$ \\
$\alpha_{6}$ & $99 \cdot 7(0 \cdot 4)$ & $199 \cdot 1(33 \cdot 5)$ \\
$\alpha_{\mathrm{v}}$ & $98 \cdot 9(0 \cdot 4)$ & $39 \cdot 6(6 \cdot 6)$ \\
$\beta_{1}$ & $95 \cdot 4(5 \cdot 1)$ & $39 \cdot 9(20 \cdot 6)$ \\
Indifferent IgG & $2 \cdot 4(0 \cdot 7)$ & $2 \cdot 8(1 \cdot 2)$ \\
\hline
\end{tabular}

Composite of integrin subunit expression on HT-29 cells. Integrin expression was analysed by flow cytometry with specific primary antiintegrin antibodies and fluorescent second antibody. Values are mean (SD) of three independent experiments. 
inhibition of HT-29 cell adhesion to these extracellular matrix components, cells were preincubated with varying concentrations of monoclonal antibodies against integrin subunits for one hour at $4^{\circ} \mathrm{C}$ before seeding on coated microwells.

STATISTICAL ANALYSIS

Statistical significance was determined by the Wilcoxin rank test at $\mathrm{p}<0 \cdot 05$.

\section{Results}

EXPRESSION OF $\beta_{1}$ INTEGRINS IN CELL MEMBRANES OF COLORECTAL CARCINOMAS AND NORMAL COLONIC MUCOSA

Expression of $\beta_{1}$ integrins by normal colonic epithelial cells and malignant epithelial cells from colorectal carcinomas was examined with the immunoblot technique. With a $\beta_{1}$ chain specific antibody, expression of a characteristic $\beta_{1}$ chain (130 kD under reducing and $116 \mathrm{kD}$ under non-reducing conditions) could be shown in isolated basolateral cell membranes of normal colonic mucosa. By contrast, in cell membranes of colorectal carcinomas, two bands representing the mature $\beta_{1}$ and the $\beta_{1}$ precusor form (105 kD under non-reducing conditions) were detected in five of eight carcinomas (Fig 1). In three carcinomas a broad $\beta$ chain $(100-115 \mathrm{kD})$ was stained, indicating that a putative pre $\beta$ and $\beta$ chain were not completely separated under these experimental conditions.

EXPRESSION OF INTEGRINS ON HT-29 CELLS

In an attempt to further identify cell adhesion receptors, flow cytometry was performed with antibodies against various $\alpha$ and $\beta$ subunits of integrins. Flow cytometric analysis showed that HT-29 cells expressed $\alpha_{1}, \alpha_{2}, \alpha_{3}, \alpha_{6}, \alpha_{v}, \beta_{1}$, and $\beta_{4}$ chains of integrin cell adhesion receptors. No positive cell staining was seen with monoclonal antibodies against the $\alpha_{4}, \alpha_{5}, \beta_{2}$, and $\beta_{3}$ chains. The specificity of the antibodies was further confirmed by immunoprecipitation of integrin chains from cell lysates after ${ }^{125} I$-lactoperoxidase cell surface labelling with the indicated antibodies. In accordance with flow cytometry, we identified the $\alpha_{1}, \alpha_{2}, \alpha_{3}, \alpha_{6}, \alpha_{v}, \beta_{1}$ and $\beta_{4}$ integrin subunits in HT-29 cell membranes. Also, no $\alpha_{4}$, $\alpha_{5}, \beta_{2}$, and $\beta_{3}$ chains of integrins were detected (data not shown).

EFFECT OF DNJ AND DMJ ON THE CELL SURFACE EXPRESSION OF $\beta_{1}$ INTEGRINS ON HT-29 CELLS The amount of integrins expressed on the surface of inhibitor treated and untreated cells was analysed by indirect immunofluorescent staining with monoclonal antibodies against integrin subunits followed by flow cytometric analysis on a FACSCAN (Becton-Dickinson) flow cytometer. This analysis showed that HT-29 cells express the $\alpha_{1}, \alpha_{2}, \alpha_{3}, \alpha_{6}$, and $\beta_{1}$ chain of the integrin cell adhesion receptor family. Also, significant expression of the $\alpha_{v}$ chain was found (see Table). No positive cell staining was seen if monoclonal

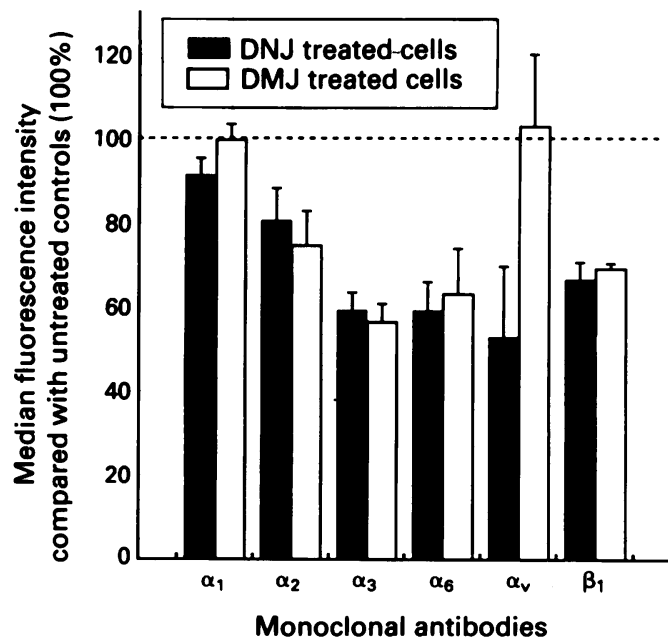

Figure 2: Effect of deoxymannojirimycin (DMF) and deoxynojirimycin (DNF) on the expression of integrin chains on HT-29 cells. HT-29 cells were treated for 48 hours with $3 \mathrm{mM}$ DMF (open columns) or DNF (dark columns) or left untreated. These cells were incubated with monoclonal antibodies against integrin chains and bound antibody was stained with fluorescein conjugated second antibodies. Cells were analysed by flow cytometry and the median staining intensity of untreated cells was set at $100 \%$. Columns represen mean $(S D)$ of four independent experiments.

antibodies against the $\alpha_{4}$, the $\alpha_{5}$, the $\beta_{2}$, and the $\beta_{3}$ chains were used. Figure 2 shows that treatment of HT-29 cells with DNJ and DMJ for 48 hours reduced the expression of $\alpha_{3}, \alpha_{6}$, and $\beta_{1}$ to $55 \%$ to $70 \%$ of that of untreated controls. Reduction of $\alpha_{2}$ staining was less intense (70\%$80 \%$ ) and staining intensity of the $\alpha_{1}$ chain was not significantly altered. The staining intensity of all these integrin chains was similar in DNJ and DMJ treated HT-29 cells. By contrast, the expression of the $\alpha_{\mathrm{v}}$ containing fibronectin binding integrin was reduced to $53 \%$ by treatment with DNJ but was not altered by DMJ.

\section{STRUCTURE OF $\beta_{1}$ INTEGRINS ON HT-29 CELLS} TREATED WITH DMJ OR DNJ

The effect of $\mathrm{N}$-linked oligosaccharide trimming and processing on the molecular weight of $\beta_{1}$ integrins on HT-29 cells was investigated with specific inhibitors of glucosidase I (DNJ) and mannosidase I (DMJ). Equivalent numbers of HT-29 cells were incubated for 48 hours with $3 \mathrm{mM} \mathrm{DNJ}$ or DMJ or left untreated. Cell surface molecules were then labelled with ${ }^{125} \mathrm{I}$, and the $\alpha \beta$ heterodimers containing $\beta_{1}$ were immunoprecipitated with $\mathrm{mAb} 4 \mathrm{~B} 4$ and resolved by SDS-PAGE. As described previously, $\beta_{1}$ integrins on the cell surface of untreated cells migrate under non-reducing conditions as three major bands: a strong signal averaging at $115 \mathrm{KD}$ representing the mature $\beta_{1}$ subunit, a broad signal between $140-160 \mathrm{KD}$ at positions of the $\alpha_{2}, \alpha_{6}$, and $\alpha_{v}$ chains, and a weak signal at 200 KD of the $\alpha_{1}$ chain (Fig 3). Inhibition of the mannosidase I for 48 hours by DMJ results in the cell surface expression of the minor pre- $\beta_{1}$ chain of about $105 \mathrm{KD}$ and a minor $\alpha_{1}$ chain of about $190 \mathrm{kD}$. As well as the $\alpha$ chain band at $140-160$ $\mathrm{kD}$ a further signal was seen at $130 \mathrm{kD}$. Immunoprecipitation experiments with monoclonal antibodies against $\alpha$ subunits showed that this pre- $\alpha$ band mainly contains the smaller forms of $\alpha_{3}$ and 
$\alpha_{\mathrm{v}}$ chains, whereas the molecular weight of the $\alpha_{2}$ chain is not altered by DMJ treatment (data not shown). After inhibition of the glucosidase I by DNJ no change in the molecular weight of the integrin subunits was found.

\section{KINETICS OF TURNOVER OF $\beta_{1}$-INTEGRINS ON} HT-29 CELLS IN THE PRESENCE OF DMJ

HT-29 cells were incubated with the mannosidase I inhibitor DMJ for various times and $\beta_{1}$ integrins were immunoprecipitated from ${ }^{125} I-$ surface labelled cells and analysed by SDSPAGE followed by autoradiography. After four hours of incubation with DMJ, no pre- $\beta$ chains were found and after a 12 hour incubation period, most of the $\beta_{1}$ integrin complexes on the cell surface still contained the mature $\beta_{1}$ chain but some the smaller pre- $\beta_{1}$ chain (Fig 4). After a 24 hour incubation with DMJ, $50 \%$ of $\beta_{1}$ integrins were replaced by pre- $\beta_{1}$ containing integrins. After a 48 hour incubation period, most $\beta_{1}$ integrins contained the pre- $\beta$ chain. These data indicate a half life of $\beta_{1}$ integrins on HT-29 cells of about 20-24 hours under these experimental conditions, but we cannot rule out the probablity that in the presence of DMJ the turnover rate of these adhesion receptors differs from that of untreated cells.

\section{ADHESION OF HT-29 CELLS TO VARIOUS}

\section{EXTRACELLULAR MATRIX COMPONENTS}

We first investigated the adhesion of HT-29 cells to various extracellular matrix components. Figure 5 shows that the time course of HT-29 cell adhesion to these substrates was remarkably different. After six hours of incubation, HT-29 cells showed maximal adhesion to type IV collagen. An increase in the incubation time did not change plating efficiencies (data not shown) and plateau values for adhesion to type IV

Figure 3: SDS-PAGE analysis of $\beta_{1}$ integrins from ${ }^{125}$ I cell surface labelled $H T-29$ cells treated with DNF or DMF. HT- 29 cells were cultured for 48 hours in the presence of $3 \mathrm{mM} \mathrm{DMF}$ or DNF or left untreated. Cells were surface labelled with ${ }^{125}$ I by the

lactoperoxidase method. Cell lysates were

immunoprecipitated with the monoclonal antibody $4 B 4$ against the $\beta_{1}$ integrin subunit and precipitates were resolved in $7 \%$

polyacrylamide gels under non- reducing conditions. Arrows on the left indicate molecular weight marker positions, arrows on the right indicate positions of mature and precursor integrin subunits. Abbreviations as for Figure 2. collagen varied between $80 \%$ and $85 \%$ of total cells seeded. With this rate of adhesion set as $100 \%$, only $2.5(1) \%$ (mean (1 SD)) of the cells adhered to BSA in serum free medium after six hours. Within 30 minutes, only $0.5(0.2) \%$ of cells adhered to BSA $v$ to 81 (9)\% to type IV collagen. A significant adhesion after six hours was also found for laminin $(76(10 \%))$ and fibronectin $(66(7) \%(p<0.001)$ (Fig 2). Under all experimental conditions, HT-29 cells showed a greater adhesion to type IV collagen than to laminin or fibronectin.

\section{INTEGRIN MEDIATED CELL ADHESION OF HT-29} CELLS

To define more precisely the interaction between HT-29 cells and extracellular matrix components, we tested the effect of added antibodies against different integrin chains. Adhesion of HT-29 to laminin is mediated by the $\alpha_{6} \beta_{1}$ integrin complex, as the monoclonal antibody 4B4 directed against the integrin $\beta_{1}$ chain and the monoclonal antibody GOH3 against the $\alpha_{6}$ chain abolished cell adhesion to laminin (Fig 6). Pretreatment of HT-29 cells with monoclonal antibodies against $\alpha_{1}$ or $\beta_{1}$ significantly inhibited cell adhesion to type IV collagen, indicating that HT-29 adhesion to the basement membrane component type IV collagen as well as to laminin is mediated by $\beta_{1}$ containing integrins. With fibronectin substrates on the other hand, only the monoclonal antibody against the $\alpha_{\mathrm{v}}$ chain was inhibitory. These results indicated that $\alpha_{\mathrm{v}}$ containing integrins are essential for adhesion of these tumour cells to fibronectin.

EFFECT OF DNJ AND DMJ ON CELL ADHESION TO LAMININ, TYPE IV COLLAGEN, AND FIBRONECTIN To examine the function of $\beta_{1}$ integrins on DMJ or DNJ treated HT-29 cells, we assayed the

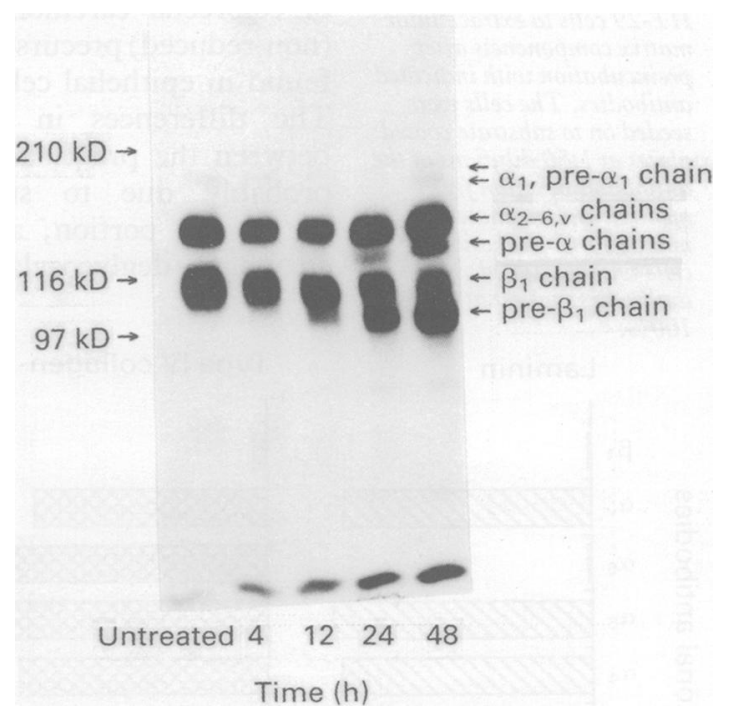

Figure 4: Time course of the effect of DMF on $\beta_{1}$ integrin expression. $H T-29$ cells were cultured for four hours, 12 hours, 24 hours, or 48 hours in the presence of $3 \mathrm{mM} \mathrm{DMF}$ or left untreated. Immunoprecipitates with monoclonal antibodies against the integrin $\beta_{1}$ chain from ${ }^{125} I$ surface labelled cells were analysed in $7 \%$ polyacrylamide gels under non-reducing conditions. Shown are autoradiographs with molecular weight marker positions on the left and integrin subunit positions on the right. Abbreviations as for Figure 2. 
Figure 5: Time course for the adhesion of HT-29 cells to laminin, type IV collagen, fibronectin, and bovine serum albumin (BSA) in vitro at $36^{\circ} \mathrm{C}$. All dishes were coated with $5 \mu \mathrm{g} / \mathrm{cm}^{2}$ of substrate for 90 minutes at $36^{\circ} \mathrm{C}$. At the indicated times, unattached cells were removed by washing and adherent cells were stained with amido black and counted. Values are the median of three independent experiments. In each experiment 10 microwells were coated with the different substrates. (SD $<10 \%$ in all experiments; ${ }^{\star} p<0.05$ v $B S A$, ${ }_{\star \star \star} p<0<0.001$ v $\left.B S A\right)$

Figure 6: Adhesion of HT-29 cells to extracellular matrix componenets after preincubation with indicated antibodies. The cells were seeded on to substrate coated plates at 1:50 dilutions of the antibodies in serum free medium and incubated for 90 min at $36^{\circ} \mathrm{C}$. Adhesion of cells without added antibodies was set at $100 \%$.

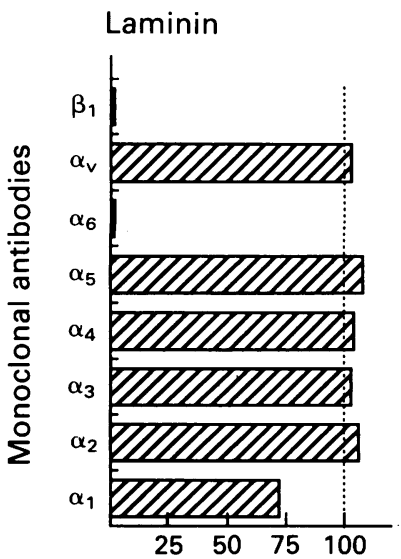

Attached cells compared with untreated controls $(100 \%)$
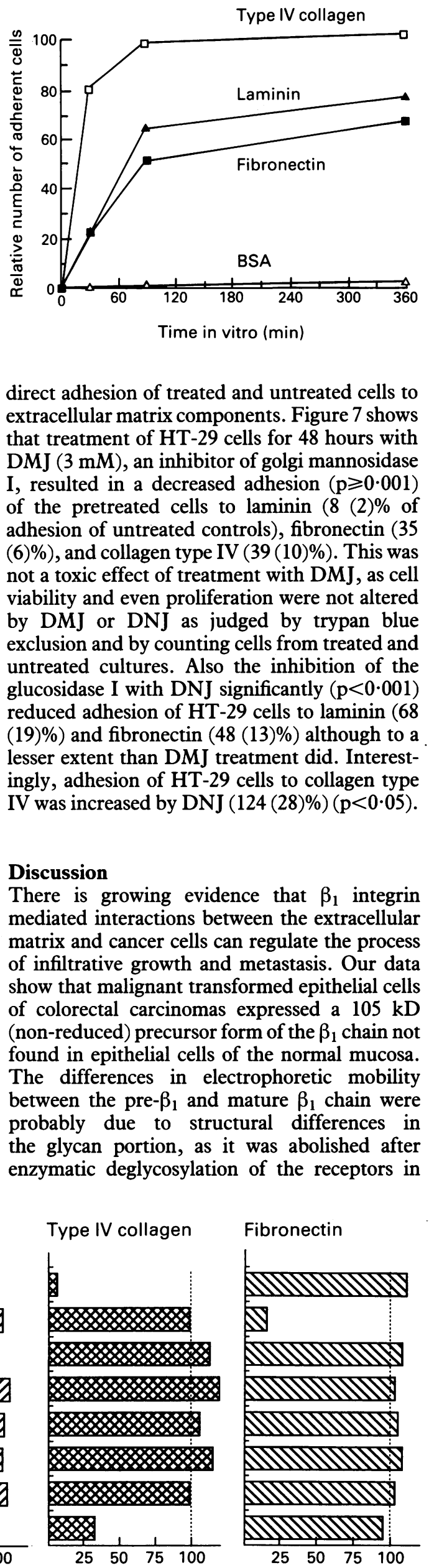

direct adhesion of treated and untreated cells to extracellular matrix components. Figure 7 shows that treatment of HT-29 cells for 48 hours with DMJ ( $3 \mathrm{mM})$, an inhibitor of golgi mannosidase $I$, resulted in a decreased adhesion $(p \geqslant 0.001)$ of the pretreated cells to laminin ( $8(2) \%$ of adhesion of untreated controls), fibronectin (35 (6)\%), and collagen type IV (39(10)\%). This was not a toxic effect of treatment with DMJ, as cell viability and even proliferation were not altered by $\mathrm{DMJ}$ or $\mathrm{DNJ}$ as judged by trypan blue exclusion and by counting cells from treated and untreated cultures. Also the inhibition of the glucosidase I with DNJ significantly $(p<0.001)$ reduced adhesion of HT-29 cells to laminin (68 (19)\%) and fibronectin (48 (13)\%) although to a lesser extent than DMJ treatment did. Interestingly, adhesion of HT-29 cells to collagen type IV was increased by DNJ (124 (28)\%) ( $p<0.05)$.

\section{Discussion}

There is growing evidence that $\beta_{1}$ integrin mediated interactions between the extracellular matrix and cancer cells can regulate the process of infiltrative growth and metastasis. Our data show that malignant transformed epithelial cells of colorectal carcinomas expressed a $105 \mathrm{kD}$ (non-reduced) precursor form of the $\beta_{1}$ chain not found in epithelial cells of the normal mucosa. The differences in electrophoretic mobility between the pre- $\beta_{1}$ and mature $\beta_{1}$ chain were probably due to structural differences in the glycan portion, as it was abolished after enzymatic deglycosylation of the receptors in

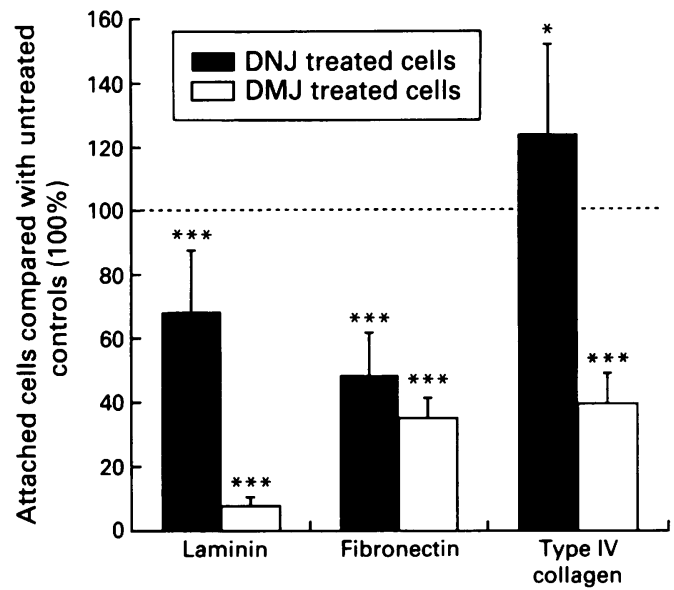

Figure 7: Adhesion of HT-29 cells to extracellular matrix components after treatment for 48 hours with $3 \mathrm{mM} \mathrm{DMF}$ (light) or DNF (dark) in culture medium. Treated and untreated cells were seeded on to microwell plates and coated with the indicated substrates. After 90 minutes, the plates were washed, and bound cells were counted. Adhesion of untreated cells was set at $100 \%$. Values are means $(S D)$ of quadruplicate wells of three separate experiments; ${ }^{\star} p<0.05 \mathrm{v}$ controls; $\star \star \star p<0.001$ v controls.

normal epithelial cell membranes (data not shown). Differences in the glycosylation of cell surface components of colorectal cancer cells have been previously shown. ${ }^{14}$ That the detection of pre- $\beta$ chains in isolated cell membranes of colorectal carcinomas with the immunoblot technique reflects contaminations from an intracellular pool of pre- $\beta$ polypetides cannot, however, be excluded. Akiyama et al showed that in transformed cells the turnover of $\beta_{1}$ integrins is increased, leading to a decrease in the intracellular pool of pre- $\beta$ polypeptides compared with normal cells. ${ }^{13}$ Contamination of isolated cell membranes with intracellular components would therefore probably result in the detection of pre- $\beta$ chains in the normal colonic mucosa.

To further characterise the relevance of $\mathrm{N}$-linked oligosaccharides for $\beta_{1}$ integrin receptor expression and function in malignant colonic epithelial cells, cell culture experiments were performed with HT-29 cells, cell line derived from a human adenocarcinoma. In a first attempt to characterise $\beta_{1}$ integrin cell membrane expression, flow cytometry analysis was performed with antibodies against various $\alpha$ chains of the $\beta_{1}$ family of integrins after pretreatment with DMJ or DNJ. We found that expression of various $\alpha$ subunits was modified by DNJ or DMJ treatment in different patterns. Pretreatment with DMJ and DNJ, for example, reduced expression of the $\alpha_{6}$ and $\beta_{1}$ chains to $60 \%-70 \%$ of untreated control values, whereas expression of the $\alpha_{1}$ chain remained unchanged. Expression of the $\alpha_{\mathrm{v}}$ chain mediating adhesion of fibronectin was not altered by DMJ treatment but was reduced to $53 \%$ by DNJ. A diminished receptor expression may be due to reduced membrane insertion or increased degradation of the receptor in inhibitor treated cells. In agreement with our results, Spiro et $a l^{35}$ recently reported that inhibition of the glucosidase I by DNJ delayed maturation and membrane insertion of the $\alpha_{v} \beta_{3}$ vitronectin receptor in human melanoma cells and resulted in a $50 \%$ reduced cell surface expression, whereas pre- 
treatment with DMJ did not alter the vitronectin receptor expression. Immunoprecipitation experiments from ${ }^{125}$ I labelled cells were performed to further characterise the molecular mechanisms by which inhibitors of glycosylation modify $\beta_{1}$ integrin receptor expression. We have shown that pretreatment with DNJ had no apparent effect on the molecular weight of $\beta_{1}$ integrins in HT-29 cells. By contrast, inhibition of mannosidase I with DMJ reduced the molecular weight of several $\alpha$ chains and led to the expression of the smaller $105 \mathrm{kD}$ pre- $\beta_{1}$ chain on the cell surface. Similar results were reported for DMJ treatment of fibroblasts, which blocked maturation of the pre- $\beta_{1}$ to the mature $\beta_{1}$ chain. ${ }^{13}$ Because the $\mathrm{N}$-linked oligosaccharides synthesised in the presence of DNJ contain maximally four sugar residues more than those synthesised in the presence of $\mathrm{DMJ}$, most of the 13 potential $\mathrm{N}$-glycosylation sites on the $\beta_{1}$ protein have to be glycosylated to account for the difference in molecular weight between the $b_{1}$ chains in DMJ and DNJ treated cells. The effect of DMJ was dose and time dependent, indicating a 20-24 hour half life of the $\beta_{1}$ chain in HT-29 cells under these experimental conditions.

Besides an altered expression of integrin adhesion molecules in colorectal cancer, an altered function may also result in pathological cell matrix interactions. Evidence has been found for the involvement of integrin glycosylation in the modulation of cell matrix interaction. Reduction in erythroleukaemia cell adhesion after phorbol ester treatment caused by reduced glycosylation of $\alpha_{5} \beta_{1}$ was recently reported. ${ }^{36}$ To further characterise the relevance of glycosylation of integrins for their function as cell adhesion receptors we performed initial experiments to analyse the integrin mediated cell matrix interaction in HT-29 cells, and were able to show that inhibition of golgi mannosidase I by DMJ resulted in a significantly decreased adhesion of DMJ treated HT-29 cells to laminin, type IV collagen, and fibronectin. Also inhibition of the glucosidase I by DNJ significantly reduced HT-29 adhesion to laminin and fibronectin although less effectively than DMJ treatment. Attachment of HT-29 cells to type IV collagen was increased by treatment with DMJ.

The reduced adhesion of DMJ treated HT-29 cells towards the extracellular matrix components tested cannot be simply explained by a diminished expression of integrin receptors, because the effect of DNJ on the expression of integrins was similar or greater than that of DMJ, but inhibition of cell adhesion was less efficient or absent. This suggests that the processing of $\mathrm{N}$-linked oligosaccharides is required for the function of the integrin receptors. This conclusion is further corroborated by the finding that DNJ increases the adhesion of HT-29 cells to type IV collagen despite unchanged or diminished expression of $\alpha_{1}$ and $\beta_{1}$ chains mediating this binding. A similar effect of $\mathrm{DNJ}$ on integrin mediated cell adhesion to collagens has been described for several myoblast cell lines. ${ }^{37}$ The role of glycans on integrin receptors differs from that on some higher affinity receptors examined. For example, the insulin or epidermal growth factor receptors retain surface expression if oligosaccharides are present but incompletely processed. ${ }^{38}$ In the case of the insulin receptor, the deglycosylated receptor retains its ability to bind to insulin. ${ }^{40}$

Studies on the role of glycosylation in malignancy are complicated by identification of the relevant target molecule. Recent studies have shown that inhibitors of the $\mathrm{N}$-glycan processing reduce metastatic growth of tumour cells of different histological types and origins. ${ }^{41-43}$ A change in a single enzyme will generally influence a multitude of substrate proteins and lipids. It is not easy to find out which substrate molecule is implicated in a particular phenotypic or functional change, if any. Thus it seems clear that malignant transformation can affect the expression, distribution, and function of glycosylated cell surface components such as integrins, but the pattern of changes may be complex. Our data may, however, serve as a basis for further studies aiming at the identification of regulatory factors (for example, hormones, lymphokines, cytokines) that modulate the expression and function of integrins of colorectal cancer cells. This might open up new concepts for influencing local tumour growth and metastasis of colonic malignancies.

We thank Dr A Sonnenberg and Dr V Morhenn for providing antibodies. This work was supported by Grants $\mathrm{Ri} 136 / 12-5$ of the Deutsche Forschungsgemeinschaft and a pregraduate grant of the Free University of Berlin (to BvL). We gratefully acknowledge the expert technical assistance of Petra Weininger.

1 LaMont JTh, Isselbacher KI. Diseases of the small and large intestine. In: Petersdorfer RG, Adams RA, Braunwald E, Isselbacher KJ, Martin JB, Wilson JD, eds. Harrison's principles of internal medicine. New York: McGraw-Hill,

Liotta LA, Rao CN, Barsky SH. Tumor invasion and the extracellular matrix. Lab Invest 1983; 49: 636-9.

3 Hynes RO. Integrins: a family of cell surface receptors. Cell 1987; 48: 549-54.

4 Albelda S, Buck CA. Integrins and other cell adhesion molecules. FASEB $1990 ; 4: 2868-80$

5 McIntyre BW, Bednarczyk JL, Passini CA, Szabo MC Udagawa T, Wygant JN. Integrins: cell adhesion receptors in health and disease. Cancer Bulletin 1991; 43: 51-7.

6 Rouslahti E. Integrins. F Clin Invest 1991; 87: 1-5.

7 Hemler ME, Huang C, Schwarz L. The VLA protein family: characterization of five distinct cell surface heterodimers each with a common 130.000 molecular weight $\beta$ subunit. f Biol Chem 1987; 262: 3300-9.

8 Vogel BE, Tarone G, Giancotti FG, Gailit J, Rouslahti E. A novel fibronectin receptor with an unexspected subunit novel fibronectin receptor with an unexspected
composition $\left(\alpha_{v} \beta_{1}\right)$. F Biol Chem 1990; 265: 5934-7.

9 Sonnenberg A, Linders CJT, Modderman PW, Damsky CH, Aumailly M, Timpl R. Integrin recognition of different cellbinding fragments of laminin (P1, E3, E8) and evidence that $\alpha_{6} \beta_{1}$ but not $\alpha_{6} \beta_{4}$ functions as a major receptor for fragment E8. F Cell Biol 1990; 110: 2145-55.

10 Pignatelli M, Smith MEF, Bodmer WF. Low expression of collagen receptors in moderate and poorly differentiated colorectal carcinomas. Br $\mathcal{F}$ Cancer 1990; 61: 636-8.

11 Koretz K, Schlag P, Boumsell L, Möller P. Expression of VLA $-\alpha_{2}$, VLA $-\alpha_{6}$ and VLA $-\beta_{1}$ chains in normal mucosa and adenomas of the colon and in colon carcinoma and their live metastases. Am F Pathol 1991; 138: 741-50.

12 Stallmach A, von Lampe B, Matthes H, Bornhöft G, Riecken EO. Diminished expression of integrin adhesion molecules on human colonic epithelial cells during the benign to malign on human colonic epithelial cells during the be

13 Akiyama SK, Yamada SS, Yamada MY. Analysis of the role of glycosylation of the human fibronectin receptor. $\mathcal{F}$ Biol Chem 1989; 264: 18011-8.

14 Garcia M, Seigner C, Bastid C, Choux R, Payan MJ, Reggio H. Carcinoembryonic antigen has a different molecular weigh in normal colon and in cancer cells due to $\mathrm{N}$-glycosylation differences. Cancer Res 1991; 51: 5679-86.

15 Hemler ME, Jacobson JG, Srominger JL. Biochemical characterization of VLA-1 and VLA-2. F Biol Chem 1985 260: $15246-52$.

16 Santoso S, Kiefel V, Mueller-Eckhardt C. Immunochemica characterization of the new platelet alloantigen system Bra/Brb. Br F Haematol 1989; 72: 191-8.

17 Morhenn VB, Schreiber AB, Soriero O, McMillan W, Allison AC. A monoclonal antibody against basal cells of human epidermis. Potential use in the diagnosis of cervica neoplasia. f Clin Invest 1985; 76: 1978-83. 
18 Hemler ME, Huang C, Takada Y, Schwarz L, Strominger JL, Clabby ML. Characterization of the cell surface heterodimete VLA-4. F Biol Chem 1987; 262: 11478-85.

19 Wayner EA, Carter WG, Piotowicz RS, Kunicki TJ. The function of multiple extracellular matrix receptors in mediating cell adhesion to extracellular matrix: Preparation of monoclonal antibodies to the fibronectin receptor that specifically inhibit cell adhesion to fibronectin and react with platelet glycoproteins Ic-IIa. F Cell Biol 1988; 107: 1881-91.

20 De Fries JE, Keizer GD, Te Velde AA, Voordouw A, Ruitter D, Rumke P, et al. Characterization of melanoma-associated $\mathrm{D}$, Rumke $\mathrm{P}$, et al. Characterization of melanoma-associated
surface antigens involved in the adhesion and motility of surface antigens involved in the adhesion and motility
human melanoma cells. Int $₹$ Cancer $1986 ; 38: 465-73$.

21 Sonnenberg A, Modderman PW, Hogervorst E. Laminin receptor on platelets is the integrin VLA-6. Nature 1988 336: 487-9.

22 Morimoto C, Letvin NL, Boyd AW, Hagan M, Brown HM, Kornacki MM, Schlossman SF. The isolation and characterization of the human helper inducer $T$ cell subset. $\mathcal{f}$ Immunol 1985; 134: 3762-9.

23 Hildreth JEK, Gotch FM, Hildreth PD, McMichael AJ. A human lymphocyte-associated antigen involved in cell mediated lympholysis. Eur F Immunol 1983; 13: 202-8.

24 Ruan C, Du X, Wan H, Hu X, XX, Li P. Characterization of the human platelet membrane glycoproteins IIb/IIIa. the human platelet membrane

25 Hessle H, Sakai LY, Hollister DW, Burgeson RE, Engvall E. Basement membrane diversity detected by monoclonal antibodies. Differentiation 1984; $26: 49-54$

26 Maeda T, Balakrishnan K, Mehdi SQ. A simple and rapid method for preparation of plasma membranes. Biochem Biophys Acta 1983; 731: 115-20.

27 Evans WH. Preparation and characterisation of mammalian plasma membranes. In: Work TS, Work E, eds. Laboratory techniques in biochemistry and molecular biology. Amsterdam: North Holland, 1978: 107-8.

28 Laemmli .UK. Cleavage of structural proteins during the assembly of the head of bacteriophage T4. Nature $1970 ; 227$ : 680-5.

29 Towbin H, Stachlin T, Gordon J. Elektophoretic transfer of proteins from polyacrylamide gels to nitrocellulose sheets: Procedure and some applications. Proc Natl Acad Sci USA 1979; 76: 4350-4.

30 Ogier-Denis E, Trugnan G, Sapin C, Aubery M, Codogno P. Dual effect of 1-deoxymannojirimycin on the mannoses uptake and on the $\mathrm{N}$-glycan processing of the human colon cancer cell line HT-29. F Biol Chem 1990; 265: 5366-9. 31 Hynes RO, Wyke JA. Alterations in surface proteins in of the Rous sarcoma virus. Virology 1975; 64: 492-504.
32 Sonnenberg A, Hogervorst F, Osterop A, Veltman FEM. Identification and characterization of a novel antigen complex on mouse mammary tumor cells using a monoclona antibody against platelet plycoprotein Ic. $\mathcal{F}$ Biol Chem 1988 263: $14030-8$.

33 Adams JC, Watt FM. Change in keratinocyte adhesion during terminal differentiation: Reduction in fibronectin binding precedes $\alpha_{5} \beta_{1}$ integrin loss from the cell surface. Cell 1990 ; 63: 425-35.

34 Stallmach A, Schuppan D, Dax J, Hanski C, Reicken EO. Identification of laminin binding proteins in cell membranes of a human colon adenocarcinoma cell line. Gut 1990; 31: $70-6$.

35 Spiro RC, Laufer DM, Perry SK, Harper JR. Effect of inhibitors of $\mathrm{N}$-linked oligosaccharide processing on the cell surface expression of a melanoma integrin. F Cell Biochem 1989; 41 : $37-45$.

36 Symington BE, Symington FW, Rohrschneider LR. Phorbol ester induces increased expression, altered glycosylation and reduced adhesion of $\mathrm{K} 562$ erythroleukemia cell fibronectin receptors. F Biol Chem 1989; 264: 13258-66.

37 Trudel GC, Holland PC. The glycoprotein-processing inhibitors bromoconduritol and N-methyl-1-deoxynojirimycin alter the adhesion phenotype of skeletal myoblasts. Biochem alter the adhesion phenotyp
Cell Biol 1990; 68: 1411-8.

38 Breitfeld PP, Rup D Schwartz AL. Influence of $\mathrm{N}$-linked oligosaccharides on the biosynthesis, intracellular routing oligosaccharides on the biosynthesis, intracellular routing
and function of the human asialoglycoprotein receptor. f Biol Chem 1984; 259: 10414-21.

39 Duronio V, Jacobs S, Romero PA, Herscovics A. Effects of inhibitors of $\mathrm{N}$-linked oligosaccharide processing on the biosynthesis and function of insulin and insulin like growth factor I receptors. F Biol Chem 1988; 263: 5436-45.

40 Olson TS, Lane MD. Posttranslational acquisition of insulin binding activity by the insulin proreceptor. Correlation to recognition by autoimmune antibody. F Biol Chem 1987; 262: 6816-22.

41 Humphries MJ, Matsumoto $\mathrm{K}$, White SL, et al. Oligosaccharide modification by swainsonine treatment inhibits pulmonary colonization by B16-F10 murine inhibits pulmonary colonization by Bl6-F10 murine melanoma

42 Pulverer G, Beuth K, Ko HL, et al. Glycoprotein modification of sarcoma L-1 tumor cells by tunicamycin, swaisonine, bromoconduritol or 1-deoxynojirimycin treatment inhibits their metastatic lung colonization in $\mathrm{BALB} / \mathrm{c}$ mice. $\mathcal{F}$ Cancer Res Clin Oncol 1988; 114: 217-20.

43 Newton SA, White SL, Humphries MJ, et al. Swainsonine inhibition of spontanous metastasis. $\mathcal{F}$ Natl Cancer Inst 1989; 81: 1024-8. 